\title{
Aid Targeting in Post Conflict Nepal
}

\author{
Marco Binetti \& Martin C. Steinwand* \\ University of Essex
}

*Corresponding author: martin.steinwand@essex.ac.uk

\begin{abstract}
International aid plays an important role in the reconstruction of post-conflict societies, but its effectiveness depends on whether aid reaches the neediest recipients. We study how power sharing in Nepal's post-conflict transition affected the political capture of aid. We argue that despite the explicit inclusion of disadvantaged groups in the

Comprehensive Peace Agreement from 2006 and the 2007 Interim Constitution, districts that neither aligned with the Maoist insurgents nor the government during the civil war remained politically disadvantaged. We present statistical evidence that districts that did not support any of the former warring factions receive systematically less aid during the post-conflict period, regardless of economic need or damage caused by fighting. However, the main parties do not appear to actively target their own supporters with higher aid allocations. We conclude that the political settlement after the conflict enfranchised Maoist insurgents' supporters, but not other marginalized groups.
\end{abstract}




\section{Introduction}

International aid plays an important role in the reconstruction of post-conflict societies. Yet, its capacity to promote reconciliation, political stability and economic development crucially depends on whether reconstruction programs address the underlying causes of conflict and whether aid reaches the intended recipients. Outside of post-conflict settings, aid frequently is at risk of being captured by powerful political interests (e.g. Bueno de Mesquita \& Smith 2009, Winters 2014). Post-conflict environments might differ if a civil war ended with a peace agreement. First, the political settlement often explicitly promises better distributional outcomes to disenfranchised groups. Second, the international donor community frequently is invested in underwriting the new political order and should actively seek to avoid aid capture. We investigate this dynamic studying the role of the Comprehensive Peace Agreement (CPA) that ended the Nepalese Civil War in 2006 and the Interim Constitution of 2007 for ensuring power sharing and avoiding political capture of aid. In particular, we explore whether the agreement was successful in suppressing the partisan allocation of aid flows to supporters of the party in power, and whether the agreement's stated goal of enfranchising previously marginalized groups was achieved.

Post-conflict aid ideally helps to rebuild destroyed infrastructure, replenish physical capital (Kang \& Meernik 2005) and typically coincides with an uptick in economic activity (Collier \& Hoeffler 2004). Notably it can play an important role in addressing grievances that have fueled the conflict (Savun \& Tirone 2012). Though experimental work has generated important insights about the effectiveness of local interventions (e.g. Mansuri \& Rao 2004, Fearon et.al. 2009), much less is known about which population groups benefit from aid flows (Findley 2018). This is because of data limitations and a lack of theory regarding the political economy of aid allocations. To address this gap, we develop arguments how peace agreements affect aid flows, combining literatures on patronage and 
political stability. We also leverage sub-national information, bringing together data on aid allocations (AidData 2017), information on politically relevant groups based on casualty data (Joshi \& Subodh 2015) and elections results (Election Commission of Nepal; Kollman et al. 2011), as well as census data (Open Nepal data hub).

Nepal presents an ideal case to study how a peace agreement affects aid flows and thus the prospects of political stability. The country has experienced a major civil war (1996 2006) and relatively successful peace process. The reconstruction period is well defined as beginning with the 2006 Peace Agreement and the 2007 Interim Constitution, and ending with the devastating earthquake in 2015. The earthquake reshaped reconstruction needs and international aid flows and also broke an inter-party stalemate about the final political settlement, ushering into the adaptation of the 2015 Constitution. Nepal is heavily aid dependent, as aid accounts for roughly one third of government expenditure (World Bank 2016). Nepalese society is characterized by strong inequalities between the center (Kathmandu) and the periphery. These differences also run along ethnic, class and geographic lines. The Maoist insurgency that fueled the civil war drew on grievances associated with these cleavages. The different social dimensions of the conflict do not map perfectly into each other, making the country a fertile testing ground for exploring how different population groups fared in receiving aid transfers during the country's reconstruction period. There is also useful variation in the governing arrangements in this time. Between the first post-war elections in 2008 and the second round in 2013, changing governing coalitions have included the insurgent Communist Party of Nepal (Maoist) (hereafter CPN(M) or Maoists), and the main parties of government during the conflict, the Nepali Congress (NC) and the Communist Party of Nepal (Unified Marxist Leninist) (hereafter UML). 
To study the effect of the CPA and Interim Constitution, we focus on variation in support for the former warring factions across different regions of Nepal. The conventional logic of clientelism in aid allocations suggests that areas that provided the Maoists with most support during the civil war should stand to receive more aid when the Maoist are in power, and likewise for government supporting areas and the NC and UML. However, the Peace Agreement recognized wider social justice issues and promised a more equitable treatment of groups. From this perspective, civil war allegiance should be no important determinant of post-conflict support, at least not once objective reconstruction and other measures of need are taken into account.

The CPA also promised to enfranchise population groups who did not openly align with the warring faction during the civil war, and these promises also feature prominently in the Interim Constitution of 2007. While peace agreements often focus on the concrete mechanisms of power sharing, appeals to wider social justice are not as common. This makes the Nepalese peace process stand out, but also raises the important question whether marginalized population groups in Nepal in fact benefited from the reconstruction process, regardless of their participation in the conflict and representation during peace negotiations. Non-belligerents can't credibly threaten future violence, and therefore are not part of the process that seeks to commit belligerents to lay down their arms. As a result, the risk increases that such groups fall by the wayside during the reconstruction phase and have their needs not addressed. This in turn carries with it the seeds for future grievances and renewed conflict.

The implication of these considerations for Nepal are twofold. First, if the political process was successful in achieving the social goals laid out in the Peace Agreement and the Interim Constitution, aid allocations should have not shown marked signs of benefiting the party in power. In addition, they should have reflected the economic needs of different 
regions, regardless of whether people in these regions participated in fighting. Alternatively, if the process was unsuccessful in reaching these aims, aid allocations would have followed detectable patronage patterns, benefiting supporters of the party in power. Areas that sided with either of the factions that negotiated the CPA should have been better served with aid projects in the reconstruction phase than areas in which the population did not side with either the government or the Maoist insurgents. Such an outcome would mean that the Nepalese peace process has created a framework which perpetuates inequalities and allows new grievances to grow, seeding the conditions for renewed conflict, albeit between new opposing factions.

To preview results, we find that there are no overt patterns of aid allocations benefiting either the supporters of the $\mathrm{CPN}(\mathrm{M})$ nor the UML, when these parties were in control of the crucial Ministry of Peace and Reconstruction. The peace process therefore seems to have successfully avoided clientelism among the former warring factions. However, marginalized areas which support neither of the main parties systematically receive lower aid allocations.

This article makes a number of contributions. First, previous works find that peace agreements can be successful in producing sustainable peace if they pay attention to distributional justice (Druckman \& Albin 2011). In contrast, our findings highlight that even if an agreement succeeds in drafting former combatants into the political process, groups that did not participate in the armed struggle are at risk of continued marginalization. Second, foreign aid constitutes an important source of income in post-conflict countries, and allocating aid to where it is needed most is a precondition for successful economic recovery. Our results show that allocative efficiency is not easy to achieve, even if a peace agreement and new constitution formally acknowledge the need for greater equality. Finally, the study identifies political misallocation of reconstruction aid as a potentially 
important source of the often observed gap between the stated policy goals of western donor governments and realized development outcomes.

In the following, we first present the case for our thesis in the context of the Nepalese civil war. We then turn to the existing academic literature on post-conflict development aid and articulate our central argument more fully. In the succeeding section we discuss data and methodological choices for the statistical analysis, followed by a presentation of the empirical results. We conclude with a summary of our findings.

\section{Fighting patterns and aid allocations in Nepal}

Our central argument is that social goals enshrined in a peace agreement are at risk of failure if a) the political settlement enables the allocation of reconstruction aid to follow a spoils politics logic, and b) non-combatant groups systematically benefit less from post-conflict distributional settlements than those groups who sided with the insurgents or the government. It is important to highlight that these two sources of failure can operate independently. For example, former combatant groups can be equally well served with reconstruction aid, irrespective of who holds political power, thus breaking the spoils logic. Yet, previously marginalized groups that did not take up arms may continue to be shortchanged. Likewise, in principle it is possible that non-combatant groups themselves can engage in spoils politics, though in reality it is less likely that such groups accede to the levers of power. Before developing these arguments in more detail below, we illustrate how they apply to the case of Nepal's civil war and post-conflict politics.

Nepalese society at the beginning of the Maoist uprising in 1996 was characterized by strong social and economic divisions along a large number of cleavages. These included a geographic dimension, with Kathmandu as center of economic and political activity, and less advantaged regions, in particular the Mid- and Far West. There were strong inequalities 
along caste and ethnic lines, as well as concentrated land holdings and leftovers of a feudal system that rewarded civil servants with the right to exploit large tracts of land (Deraniyagala 2005, Joshi Mason 2007, Lawoti 2010, 2012, Sharma Et Al. 2014). Moreover, there existed strong gender disparities. At the same time, the country was set on a path to modernization, with the first multi-party elections held only in 1991, after a history of monarchical rule. The elections had raised expectations about social improvements, which in turn went unfulfilled (Shakya 2012). The relative contribution of these pervasive inequalities in Nepalese society to the outbreak of the civil war is contested. Commentators using qualitative narratives tend to highlight them as driving force of the conflict (e.g. Deraniyagala 2005). In contrast, more systematic statistical studies come to contradicting results, attributing fighting activity variously to poverty and geographic remoteness though not inequality (Do \& Iyver 2010), geography and inequality (Murshed \& Gates 2005), and road density but not poverty or inequality (Acharya 2009). Despite this mixed picture, it is a fact that the Maoist insurgency broke out in one of the most economically and socially deprived regions of the country, and quickly found strong support there. In addition, the programmatic demands of the $\mathrm{CPN}(\mathrm{M})$ insurgents centered on overcoming historic inequalities (Huang 2016).

Prior to the civil war, spoils politics in Nepal was not based on membership in a majority ethnic group, but manifested itself in a number of ways. The rewards from holding power disproportionally went to privileged landowners, who benefited from a skewed distribution of land holding together with weak enforcement of tenant rights (Sharma et al. 2014), civil servants, and elites located in the politically and economic dominant Kathmandu valley.

These varied sources of division are reflected in the CPA from 2006 and the 2007 Interim Constitution, which explicitly promised to address injustices towards "women, 
Dalit, indigenous people, Madhesi, oppressed, excluded and minority communities and backward regions", as well as ending discrimination based on "class, caste, language, gender, culture, religion and region". (Para 33 (d)). Power sharing was written into the Interim Constitution with a minimum 1/3 quota for women in the Constituent Assembly, and provisions for parties to "ensure proportional representation of women, Dalit, oppressed communities/ indigenous peoples, backward regions, Madhesi and other Classes, as provided in law." (Para 63(4)) ${ }^{1}$

In the empirical analysis, we leverage some of these cleavages to create a statistical baseline model under the assumption that post-conflict aid allocations in Nepal were in fact driven by economic needs and social justice concerns. We then enrich this model with variables that capture spoils politics and the combatant status of different population groups.

Given the non-ethnic nature of cleavages in the Nepalese civil war (or rather acknowledging the absence of a majority ethnic cleavage), we conceptualize spoils politics as being centered around the degree of support for the Maoist insurgency on the one hand and the government forces on the other hand. It is well documented by the literature that support for the CPN(M) strongly correlated with a sense of grievances towards elites and the government in the Kathmandu valley. For example, although the Maoists used strategic violence to intimidate local populations into supporting them, removing local elites by force and granting ownership rights to peasants who worked the land was highly popular among local populations (Lawoti 2010). In fact, Maoist indoctrination directly sought to appeal to social rights, arguably playing an instrumental role in creating long-lasting political activism among disadvantaged groups. The resulting political activism has outlasted the end of the conflict (Huang 2016).

\footnotetext{
${ }^{1}$ The 2015 Constitution which replaced the Interim Constitution retained these provisions.
} 
Given this context, we focus on aid allocations channeled towards geographic regions that were ideologically aligned with either the Maoist insurgency or the main government parties as evidence of spoils politics in the immediate post-conflict years in Nepal. The main parties in power during the conflict were the Nepali Congress and the Communist Party of Nepal (Unified Marxist-Leninist). The CPN(M) enjoyed surprising electoral success in the 2008 Constituent Assembly elections, and in the following years shifted in and out of government responsibility. We focus on the Ministry of Peace and Reconstruction as key resort for influencing the flow of reconstruction aid and investigate whether regions aligned with the $\mathrm{CPN}(\mathrm{M})$ or the UML received higher aid commitments during the years that the respective party was in power (the NC ended up politically sidelined).

While fighting eventually encompassed most of Nepal, support for the CPN(M) and the government side was not evenly distributed. For example, the Maoists struggled to find support in the low lying Terai, a region which historically also has harbored mistrust against the Kathmandu elites (Kantha 2010). A lack of partisan attachments meant a lack of voice during the peace negotiations. Tellingly, violent protests erupted among Madhesi groups in the region in the intermediate aftermath of the signing of the Interim Constitution in 2007. The protests succeeded in ensuring greater legislative presentation of the region in the upcoming elections that year. ${ }^{2}$ However, this well publicized incident illustrates the challenges faced by groups that were non-aligned during the civil war. To evaluate how being on the political sidelines affected access to reconstruction aid, we compare aid flows between regions that provided major electoral support to the main parties involved in the civil war, and those regions that remained outside the political mainstream. If the Interim

\footnotetext{
${ }^{2}$ New York Times Feb 1, 2007. Accessed on 10.5.2020 at https://www.nytimes.com/2007/02/01/world/asia/01nepal.html
} 
Constitution did not succeed in lessening social inequalities, despite nominal guarantees for all marginalized groups, areas that did not support the Maoists or the Government during the conflict should end up receiving less aid, irrespective of objective needs, and spoils politics.

\section{Theoretical framework \& Literature}

The following section puts the arguments developed in this paper in the context of the existing literature. The theoretical starting point is the stylized insight that governments in poor countries frequently rely on spoils politics and anticipate potential threats of violent resistance to their rule (e.g. Padró I Miquel 2007, Dal Bó \& Powell 2009). Existing works have highlighted various aspects that foreign aid plays for spoils politics, and these take on particular salience in post-conflict situations.

From a political economy perspective, aid generally allows rulers to buy off would-be opponents or increase suppressive tactics (Bueno de Mesquita \& Smith 2009, Morrison 2009). However, reliance on aid is not cost-free. With increasing dependence on aid flows for government expenditure, the risk of unforeseen shocks to government revenue increases, potentially undermining fragile political equilibria (Nielsen et al. 2011). ${ }^{3}$ Spoils politics in combination with aid dependence introduces an element of risk, which is particularly salient in post-conflict contexts. Haass and Ottmann (2017) show that powersharing governments in post-conflict countries are prone to rent-seeking, and that this tendency is stronger in the presence of non-tax revenue such as foreign aid. Donors tying aid to the adherence of democratic norms further heighten these rent-seeking incentives (Haass 2019). Shocks to aid flows undermine both external support for democratic norms

\footnotetext{
${ }^{3}$ This risk can't be fully eliminated even if donors are willing to counteract it (Steinwand 2015).
} 
and the source of political rents. They therefore present a direct mechanism through which reconstruction aid can contribute to political destabilization.

Evidence for the role of aid in spoils politics comes from numerous studies. Briggs (2014) shows that project aid in Kenya in the 1990s overwhelmingly favored members of the president's ethnic base. Hodler and Raschky (2010) show that in countries with weak institutions, the birth region of the incumbent ruler tends to receive more aid than other regions. Further examples for political aid allocation come from pre-electoral 2005 Zimbabwe, ${ }^{4}$ post-flooding 2010 Pakistan ${ }^{5}$ and the Philippines (Atkinson, Hicken, Ravanilla 2011). Finally, Jablonski (2014) establishes that even multilateral aid allocations are not immune from domestic political pressures.

Going beyond the direct allocation of aid, as part of spoils politics, local public goods tend to benefit well defined groups that are aligned with the ruler (e.g. Franck \& Rainer 2012, Ejdemyr et al. 2017). To the extent that aid flows free up government resources, aid dependency should increase the ability of a ruler to reward supporters, even if aid allocation decisions themselves are unaffected by spoils considerations. Local public good provision is of particular importance in post-conflict societies, because fighting results in damages to

\footnotetext{
${ }^{4}$ McGreal, Chris. "Mugabe accused of using food as a political weapon in Zimbabwe," The Guardian, June 4, 2008, available at https://www.theguardian.com/world/2008/jun/04/unitednations.zimbabwe, accessed on February 2019.

Tweedie, Neil. "A hungry future for poor voters who oppose Mugabe,” Daily Telegraph (London), March 26, 2005, available at https://www.telegraph.co.uk/news/worldnews/africaandindianocean/zimbabwe/1486512/Ahungry-future-for-poor-voters-who-oppose-Mugabe.html, accessed on February 2019.

${ }_{5}^{5}$ Rashid, Ahmed, "Pakistani flood relief must start with fighting corruption," Washington Post, September 6, 2010, available at http://www.washingtonpost.com/wp-dyn/content/article/2010/09/05/AR2010090502816.html, accessed February 2019.

Crilly, Rob and McElroy, Damien, "Pakistan in Political Crisis Amid Allegations of Flooding Aid Corruption," The Daily Telegraph (London), August 23, 2010, available at http://www.telegraph.co.uk/news/worldnews/asia/pakistan/7960923/Pakistan-in-political-crisis-amidallegations-of-floodingaid-corruption.html, accessed on February 2019.

Kheshgi , Khalid and Hashash, Sara, "Pakistan Relief Effort Hampered By Corruption," The Sunday Times, August 15, 2010, available at http://www.thesundaytimes.co.uk/sto/news/world_news/Asia/article370642.ece accessed on February 2019.
} 
local infrastructure and the health and employment prospects of local populations, which in turn require greater public resources (Collier et al. 2003).

A second causal link connecting spoils politics and political instability runs through the structural features that render disadvantaged groups dissatisfied with the status quo. The literature on civil war has identified exclusion from power sources and distributional benefits as major driving force of conflict (Acemoglu \& Robinson 2000, Dal Bó \& Powell 2009), especially where cleavages run across ethnic lines (the so-called 'grievance' explanation of politics, e.g. Buhaug et al. 2008). Obviously, in post-conflict environments dissatisfaction with distributional outcomes will be a particularly sensitive issue if the conflict was driven by such grievances in the first place.

Civil wars that end with a negotiated settlement or a peace agreement are particularly well suited to test whether the logic of spoils politics can be overcome. The literature shows that compared with other outcomes (such as a stalemate or a victory), peace settlements tend to improve the balance of political power between former contestants, as former rebel groups gain political recognition. Hartzell and Hoddie (2003) show that of 38 negotiated civil war settlements between 1945 and 1998, all except eight included political power sharing terms. ${ }^{6}$ Clearly, peace agreements shape post-war political institutions, thus creating venues to "mitigate and channel societal competition", where "no single set of antagonists is capable of imposing its will” (Hatzell and Hoodie 2007, p.11).

From these observations follow three possible scenarios for the relationship between reconstruction aid and spoils politics in post-conflict societies. The first is the most normatively positive. Political settlements create venues through which the economic and political needs of previously disenfranchised groups can find expression and therefore promise to reduce inequalities and address grievances. From this perspective, peace

\footnotetext{
${ }^{6} \mathrm{Six}$ out of those eight at least featured territorial power sharing terms.
} 
agreements are a political tool to overcome spoils politics, and success is equated with expost greater equality in distributional outcomes.

However, a second scenario is that a settlement does create political mechanisms that can achieve more distributional equality, but these mechanisms depend on ongoing patronage and consequently are only open to powerful and well-organized groups. D'Arcy and Cornell (2016) provide an example of this dynamic. They illustrate how constitutional reforms in Kenya in 2010 devolved powers to the regions and succeeded in creating patronage opportunities for a large number of population groups. However, those groups that did not gain effective political representation because of their geographic settlement patterns lost out from redistribution.

In the context of a post-conflict environment, it is reasonable to assume that nonbelligerent groups are politically marginal whereas former combatants are active negotiation partners in crafting a peace agreement. Distributional gains for underrepresented non-combatant groups are therefore not guaranteed during reconstruction. Former rebel groups might be perfectly content with ensuring access to resources for their own supporters only. Such an outcome would constitute a failure to build lasting peace, since legitimate grievances will go unaddressed, with the potential to undermine long-term reconstruction and peace building goals.

In the following empirical section, we explore in detail which of these visions took hold in the aftermath of Nepal's civil war. We test the following hypotheses that summarize the case for a successful suppression of spoils politics and foreign aid in post-conflict settings:

Hypothesis 1: Aid allocations during the reconstruction phase were not influenced by political parties rewarding their supporters.

Hypothesis 2: Population groups that were not actively participating in the civil war received aid in line with their economic and social needs. 
As discussed above, we expect that either of these two hypotheses could fail, but it is not necessary for both of them to fail simultaneously.

\section{Empirical Analysis}

To address our hypotheses we use cross-section time series analysis on geographically disaggregated data. The unit of analysis are administrative districts per year, and the data cover 2008 to 2013. The choice of time period has pragmatic and conceptual reasons. Geographically disaggregated data on aid allocations is currently only available until 2013. Importantly though, the data almost completely cover the immediate reconstruction period, beginning with the 2008 Constituent Assembly election and ending with the great earthquake of 2015. This catastrophe not only caused tremendous damage and reshaped redevelopment priorities. It also prompted a final political settlement that had previously eluded the country's parties.

Our dependent variable is aid commitments measured as dollars per capita. We rely on the Nepal AIMS Geocoded Research Release that geocodes all projects from the Government of Nepal's Aid Information Management System (AIMS). ${ }^{7}$ Geocoding allows for matching projects to Nepal's 75 pre-2015 districts. We focus on commitments instead of disbursements, because political influence on allocation decisions is more readily expressed at the commitment stage. In addition, the data coverage for commitments is more comprehensive.

To detect the influence of spoils politics, we concentrate on which party held the influential office of the Minister for Peace and Reconstruction. Control of the ministry repeatedly changed hands between the $\mathrm{CPN}(\mathrm{M})$ and $\mathrm{CPN}(\mathrm{UML})$. The Nepali Congress, as

\footnotetext{
${ }^{7}$ AidData. 2016. NepalAIMS_GeocodedResearchRelease_Level1_v1.4.1 geocoded dataset. Williamsburg, VA and Washington, DC: AidData.
} 
Nepal's historic main party and the Maoists' main antagonist during the war, only held power for a few months at the beginning of the time under consideration, and therefore is excluded from this part of the analysis. We encode the years during which the $\mathrm{CPN}(\mathrm{M})$ was in charge of the reconstruction ministry as 1 , and assign 0 otherwise, and do the same for the UML. The resulting dummy variables are called Maoist $P R$ and $U M L P R$. There were a few instances in which the ministry position was vacant, but the $\mathrm{CPN}(\mathrm{M})$ provided the Minister for Local Development. We attribute these instances to Maoist PR. As a result, we identify the CPN(M) as holding power in 2008, 2011, and 2012 and the UML in 2009 and $2010 .^{8}$

To measure political support, we rely on the results of the 2008 Constituent Assembly elections. The connection between voting behavior and politicians rewarding its supporters by steering aid towards them should be straightforward. We concentrate on three parties, the Nepali Congress and CPN (UML), as largest parties that were part of multi-party politics prior to the civil war and held government power during the war, and the CPN(M), as instigator of the civil war. The data are based on published election results by the Election Commission of $\mathrm{Nepal}^{9}$ and the constituency-level elections archive (Kollman et al. 2011). Since each district did send several representatives to the Constituent Assembly, we encode the share of representatives a party was able to capture per district. In the statistical analysis, evidence of spoils politics is captured by an interaction between the vote share variables and the dummies for holding political power.

The 2008 election was atypical, as the CPN(M) enjoyed a huge electoral success which took most observers by surprise. In fact, this surge in the polls was short-lived, and the party incurred large losses in the subsequent 2013 election (dropping from 120 directly

\footnotetext{
${ }^{8}$ In case the ministry was occupied by officials from both parties in the same year, the coding attributes power to the party that held the position for at least 7 months during this year.

${ }^{9}$ http://election.gov.np/election/np
} 
elected seats to 26 , and going from 29.3 to 15.2 percent in proportional representation vote share). Arguably therefore electoral support for the CPN(M) in 2008 did not map onto the historic support base it enjoyed during the civil war. To correct for this, as an alternative measure of support for the $\mathrm{CPN}(\mathrm{M})$ we also use the number of individuals killed in combat with the Nepalese army, mapping deaths to a combatant's home district. The voting and casualty variables are correlated with $r=0.36$. Data for this come from the Individual-Level Data on the Victims of Nepal's Civil War, 1996-2006 dataset (Joshi \& Subodh, 2015). The rationale is that the guerilla tactics employed by the Maoists led to a blurring between civilians and combatants, rendering battle deaths a valid proxy for overall support for the Maoist side of the conflict. A full discussion of the drawbacks and advantages of this measure can be found in the online supplemental appendix.

To test the second hypothesis, we need to capture which population groups neither supported the Maoists nor were aligned with the government during the conflict. If the peace agreement was successful in enfranchising all parts of society, we would expect those population groups to be not systematically disadvantaged when receiving reconstruction aid. One possibility to identify population groups that abstained from taking sides in the conflict would be to rely on data of fighting activity and identify which districts contributed least to overall casualties, the reasoning being that such districts did not provide much support to either the Maoists or the central government. Unfortunately, while this is a feasible way to identify support for the Maoists, a similar logic does not hold for the government side. Joining the armed forces is likely a poor signal of ideological alignment with the government, since the country is very poor and the state with its security forces represents an important source of income. In addition, the location of fighting activity is not necessarily a good reflection of ideological support either. While in the early years the conflict was located in areas that constituted the home base of the Maoists, fighting 
eventually spread throughout much of the country. The presence of Maoists insurgents in a region invited government reactions, but the rebel's presence by itself is not necessarily indicative of support by the local populations.

To avoid these pitfalls, we rely on the same voting data as before to identify the population groups that were least aligned with either the Maoists or the government during the conflict. Specifically, we assume that low voting shares for both the CPN(M) and the major parties NC and UML are indicative for a stance against both the Maoists and the major government parties. This measurement strategy relies on the assumption that voting behavior in 2008 is a good proxy for political alignments during the conflict which ended in 2006. The main challenge to this approach is that voters who did not support either the main parties or the Maoists during fighting may have cast their vote for them after the end of the conflict anyways, perhaps anticipating that sending a UML or CPN(M) representative to parliament might be the most effective way to ensure economic benefits are brought home to their districts. The unexpected electoral success for the CPN(M) and its reversal in the subsequent election suggest that something like this was at work. However, casting this overly broad net is working in favor of our research question, since we seek to identify districts that did not support either party during the conflict. Overestimating the support basis of the major parties is a conservative measurement strategy, as those areas that did not follow the national electoral trend in 2008 are more likely to be in durable opposition to the UML, NC and CPN(M). We call the variable for aggregate electoral support for the three main parties Main parties share and the complement Other parties share. Again, these variables are coded in terms of shares of representatives each party captures in a district. 
Control variables come from the Open Nepal hub ${ }^{10}$ and the UCDP Georeferenced Event Dataset (GED) (Sundberg \& Melander 2013). Data on infrastructure, demographics, geography and the share of insurgent, civilian and army fatalities as percent of the population per district is meant to control for the intensity of fighting and the resulting need for reconstruction aid. Human development constitutes another significant source of need for aid funding. We capture this using a battery of variables including the adult illiteracy rate, the percentage of children under age five who are malnourished, and the poverty incidence rate defined as the proportion of individuals living in that area who are in households with an average per capita expenditure below the national poverty line. ${ }^{11} \mathrm{We}$ also control for the level of infrastructure in a district using as proxies the percentage of the population with access to safe water and the road density. ${ }^{12}$

To tap into regional differences, we include a set of categorical variables indicating what is known in Nepal as development region (Central, Eastern, Far-Western, MidWestern or Western), and also a proxy for the Kathmandu valley. Another proxy captures the districts where the Maoists formally announced a Jan Sarkar, or 'people's government'. These districts stand out because they were the only ones in which the Maoists created their own village- and district-level governments during the conflict. This approach follows Hachhethu (2006), Hutt (2004), Kiyoko (2008a, 2008b), Sudheer (2004) and Shneiderman and Turin (2004). Table 1 provides summary statistics of all variables.

Table 1: Summary of Variables

\begin{tabular}{lrrrrrr}
\hline & $\mathrm{N}$ & Mean & St.Dev & min & max & skewness \\
\hline Aid Per Capita & 375 & 26.314 & 69.473 & 0 & 879.166 & 8.073 \\
Peace \& Reconstruction & 375 & 1.2 & .749 & 0 & 2 & -.344 \\
$\begin{array}{l}\text { Ministry } \\
\text { UML electoral share }\end{array}$ & 375 & .198 & .281 & 0 & 1 & 1.365
\end{tabular}

${ }^{10} \mathrm{http}: / /$ data.opennepal.net/datasets

11 According to the Nepalese Central Bureau of Statistics, the official monetary poverty line in local prices was NRs 19,261 in 2011 (Pokharel 2015). As of 2011 average transaction rate, this corresponded to 0.7 US\$ per day.

12 All of these variables are available for 2011 only. 


\begin{tabular}{|c|c|c|c|c|c|c|}
\hline NC electoral share & 375 & .205 & .3 & 0 & 1 & 1.382 \\
\hline Maoist electoral share & 375 & .489 & .42 & 0 & 1 & .064 \\
\hline Main parties share & 375 & .892 & .245 & 0 & 1 & -2.387 \\
\hline Other parties share & 375 & .108 & .245 & 0 & 1 & 2.387 \\
\hline Civilian casualties & 375 & .013 & .012 & 0 & .073 & 2.766 \\
\hline Total casualties & 375 & .068 & .069 & 0 & .411 & 2.519 \\
\hline Adult illiteracy rate & 375 & 42.523 & 11.325 & 15.96 & 66.11 & .035 \\
\hline Infant malnutrition & 375 & 42.805 & 10.911 & 16.2 & 65.7 & -.155 \\
\hline Poverty Incidence & 375 & 27.664 & 13.344 & 4 & 64.1 & .611 \\
\hline Road density & 375 & 575.68 & 924.703 & 0 & 3541 & 1.414 \\
\hline $\begin{array}{l}\text { Percentage without safe } \\
\text { water }\end{array}$ & 375 & 19.831 & 12.209 & 2.14 & 48.12 & .421 \\
\hline Population $(1,000 \mathrm{~s})$ & 375 & 349.161 & 277.081 & 5.827 & 1688.131 & 1.87 \\
\hline Kathmandu & 375 & .013 & .115 & 0 & 1 & 8.486 \\
\hline Jan Sarkar & 375 & .36 & .481 & 0 & 1 & .583 \\
\hline Terai & 375 & .24 & .428 & 0 & 1 & 1.218 \\
\hline Development Region & 375 & 2.907 & 1.509 & 1 & 5 & .089 \\
\hline
\end{tabular}

Figure 3: Share of CPN(M) candidates elected per district

\section{Results}

We begin the analysis with descriptive statistics of the key variables. Figures 1 through 4 show the geographic distribution of, respectively, total aid per capita, political support for the main parties, and political support for the Maoists both electorally and in terms of 
the number of people killed by the state during fights. A few patterns emerge. First, the CPN(M), UML, and NC dominated the 2008 elections throughout much of the country. In 61 of the 75 districts, more than 80 percent of representatives where provided by one of the three parties (Figure 2). The 14 districts in which the vote share for the main parties remained below 80 percent almost all were located in the country's southern low lands, i.e. the Terai. The political stronghold of the CPN(M) lies in Nepal's Midwest region. This is where the insurgency originated, and here the party dominated in the 2008 election (Figure 3). However, the Maoists also garnered support in the Hill and Mountain areas of the Central region around Kathmandu. These areas account for much of the unexpected overall electoral success of the $\mathrm{CPN}(\mathrm{M})$. The comparison with our second measure of Maoist core support is instructive. People dying in fights with the central government mainly were at home in the Midwestern stronghold of the $\mathrm{CPN}(\mathrm{M})$, but also in the Mountain areas and Hill lands in the East (Figure 4).

Turning to aid allocations (Figure 1), per capita spending is highest in the high Mountain regions of the Midwest and West, with some Hill and Mountain areas east of Kathmandu also receiving much aid. Aid spending is somewhat lower in the Hill lands of the Midwest region, which constitute the heartland of the Maoist insurgency, and clearly lowest throughout the Terai.

Visually inspecting these patterns provides a first indication that post-conflict aid allocations were targeting the very poorest areas of Nepal in the mountainous north-west, suggesting a needs-based approach. However, there is some overlap with areas of political support for the $\mathrm{CPN}(\mathrm{M})$, and a clear lack of political support for the three main parties in the Terai, accompanied by very low aid allocations to these lowland areas. This suggests that not all of the distributive goals set out in the Interim Constitution were met during the reconstruction. 
Before drawing any firm conclusion, we need to rule out spurious correlations and therefore turn to multivariate analysis. All models were estimated using OLS and report panel-corrected standard errors (Beck \& Katz 1995). They all include a lagged dependent variable to deal with serial correlation and year-dummies to soak up variation in overall aid commitments. We start with a baseline specification that links a district's reconstruction needs, socio-economic conditions and geography to aid allocations (Table 2). If the political settlement was successful in enfranchising disadvantaged population groups, we should expect this model to do the main work in explaining aid allocations. To test this notion further, in Tables 3 and 4 we add the variables that capture patronage involving the main parties and their supporters, by including the electoral share variables for UML, NC, and $\mathrm{CPN}(\mathrm{M})$ and their respective interactions. A successful end to spoils politics would mean that both voting behavior per se and the interactions hold little explanatory power, and also don't much affect the associations revealed in the baseline model.

Finally, in Table 5 we do the same with the variable Other parties share, to explore how districts fare that provide little political support for either side of the former warring factions. Again, if the peace process was successful in enfranchising population groups beyond those aligned with the warring parties, this variable should have little effect on aid allocations while leaving the baseline model intact.

Beginning with the baseline specification in Table 2, we first separately enter the variables meant to capture (1) reconstruction needs, (2) socio-economic needs, and (3) regional effects. Somewhat surprisingly, model (1) provides no evidence that reconstruction needs as measured by casualty numbers are related to aid allocations. Perhaps this lack of association is owed to the nature of fighting in remote and underdeveloped areas, which did not result in large-scale infrastructure damage. Of the socio-economic variables, we find infant malnutrition and poverty incidence are significant 
predictors of aid allocations. Likewise, infrastructure needs as measured by a lower road density are associated with higher aid allocations. Of the region dummies, the Kathmandu valley receives substantively more aid than other districts, more than 1.6 standard deviations, despite controlling for population size, and with the full set of controls in model (4). Likewise, districts that were hosts to self-governing Maoist Jan Sarkar entities robustly receive less per capita aid. A weak negative effect for the Eastern Development Region disappears with all controls. Finally, more populous districts receive less aid per capita than more sparsely settled districts. This suggests a bias in aid allocations towards low density and potentially politically overrepresented districts.

In equation (4) all variables are entered simultaneously. Socio-economic needs continue as important drivers of aid allocations. However, effect sizes are somewhat attenuated, and infant malnutrition loses statistical significance. ${ }^{13}$ In addition, there is now a negative relationship between the total casualties from the civil war and aid allocation. Still, equation (4) paints a carefully optimistic picture of aid allocations driven by objective social and economic needs. Except for Kathmandu there appears to be no preferences for specific regions or districts that were particularly hard hit by fighting. Substantive effects of socio-economic variables are considerable. For example, for the share of people in a district living below the poverty line, moving from the mean (27.7 percent) up one standard-deviation (plus 13.3 percent), aid per capita allocations increase on average by 20 US Dollars. This increase represents 76 percent of the average per capita aid allocations for each district (26.30 Dollars).

Next we look at the evidence for spoils politics. Table 3 adds the electoral share variables for the Maoists, UML and NC to the previous specification, as well as the dummy

\footnotetext{
13 There appears to be a negative relationship between lacking access to safe water and aid allocations, but this is only weakly statistically significant.
} 
for whether the Maoists controlled the Ministry of Peace and Reconstruction (PR), table 4 repeats this exercise for UML control of the PR ministry. All models continue to have year intercepts and the regional dummy variables. Coefficients are not reported for space reasons. In the different models we interact the Maoist PR variable with the vote shares of the different parties, to identify whether aid allocations were sensitive to variations in political support for the $\mathrm{CPN}(\mathrm{M})$. If spoils politics did not play a role, we would expect that adding these partisan variables to the base model does not reveal much additional information, as voting patterns and office holding should have no great influence on aid allocations.

Beginning with model (1) we see that this is not the case and voting patterns matter. Districts that voted more heavily for the Maoists received on average more aid than other districts. There are also positive relationships for the UML and NC electoral shares, but both are estimated with more uncertainty. To disentangle which party reacted to electoral incentives and how, we first interact the Maoist PR variable separately with the vote shares of the three main parties (models 2-4). Model 2 reveals a surprising pattern. More voting for the Maoists is associated with higher aid allocations, but only if the CPN(M) itself is not in control of the Peace and Reconstruction ministry. With the CPN(M) in power, the marginal effect of adding to the Maoist electoral share can't be distinguished from zero. ${ }^{14}$ Checking for the other parties, aid allocations are not sensitive to the UML electoral share when the Maoists hold power (model 3). Model 4 shows a negative relationship between

\footnotetext{
${ }^{14}$ Chi-squared $(1 \mathrm{dgf})=0.08, \mathrm{p}>$ chi-squared $=0.78$.
} 
Table 2: OLS -- Aid Allocation as function of reconstruction needs and socioeconomic needs, 2008-2013 observations

\begin{tabular}{|c|c|c|c|c|}
\hline & $(1)$ & $(2)$ & (3) & (4) \\
\hline Adult illiteracy rate & & $\begin{array}{l}-1.217 \\
(0.892)\end{array}$ & & $\begin{array}{l}-0.526 \\
(0.779)\end{array}$ \\
\hline Infant malnutrition & & $\begin{array}{l}1.321 * * \\
(0.596)\end{array}$ & & $\begin{array}{c}0.684 \\
(0.514)\end{array}$ \\
\hline Poverty incidence & & $\begin{array}{c}2.092^{* * * *} \\
(0.783)\end{array}$ & & $\begin{array}{l}1.502 * * \\
(0.712)\end{array}$ \\
\hline Road density & & $\begin{array}{c}-0.015^{* *} \\
(0.006)\end{array}$ & & $\begin{array}{l}-0.011^{*} \\
(0.006)\end{array}$ \\
\hline $\begin{array}{l}\text { Percentage without safe } \\
\text { water }\end{array}$ & & $\begin{array}{l}-0.450 \\
(0.595)\end{array}$ & & $\begin{array}{l}-0.815^{*} \\
(0.473)\end{array}$ \\
\hline Civilian casualties & $\begin{array}{l}437.745 \\
(358.697)\end{array}$ & & & $\begin{array}{c}41.610 \\
(114.053)\end{array}$ \\
\hline Total casualties & $\begin{array}{l}-24.345 \\
(16.531)\end{array}$ & & & $\begin{array}{l}-105.149 * * \\
(41.195)\end{array}$ \\
\hline Kathmandu & & & $\begin{array}{l}113.917 * * * \\
(40.968)\end{array}$ & $\begin{array}{l}115.698 * * * \\
(38.583)\end{array}$ \\
\hline Jan Sarkar & & & $\begin{array}{l}-26.340 * * \\
(11.383)\end{array}$ & $\begin{array}{c}-11.024 * * \\
(4.532)\end{array}$ \\
\hline $\begin{array}{l}\text { Eastern Development } \\
\text { Region }\end{array}$ & & & $\begin{array}{r}-8.939 * \\
(5.239)\end{array}$ & $\begin{array}{c}-6.579 \\
(10.675)\end{array}$ \\
\hline Far Western Dev. Reg. & & & $\begin{array}{c}0.286 \\
(11.038)\end{array}$ & $\begin{array}{c}-4.987 \\
(30.929)\end{array}$ \\
\hline Mid Western Dev. Reg. & & & $\begin{array}{c}14.997 \\
(14.601)\end{array}$ & $\begin{array}{c}25.970 \\
(23.952)\end{array}$ \\
\hline Western Dev. Reg. & & & $\begin{array}{c}8.032 \\
(11.597)\end{array}$ & $\begin{array}{l}5.189 * * \\
(2.112)\end{array}$ \\
\hline Population $(1,000 \mathrm{~s})$ & & & $\begin{array}{c}-0.095 * * * \\
(0.036)\end{array}$ & $\begin{array}{c}-0.078 * * * \\
(0.026)\end{array}$ \\
\hline Year Dummies & yes & yes & yes & yes \\
\hline Observations & 375 & 375 & 375 & 375 \\
\hline R-squared & 0.070 & 0.174 & 0.158 & 0.214 \\
\hline Number of panels & 75 & 75 & 75 & 75 \\
\hline
\end{tabular}

Panel-corrected standard errors in parentheses $* * * \mathrm{p}<0.01, * * \mathrm{p}<0.05, * \mathrm{p}<0.1$ 
Table 3: OLS -- Aid Allocation as function of voter support for main parties, Maoist PR, 2008-2013 observations

\begin{tabular}{|c|c|c|c|c|c|}
\hline & $(1)$ & (2) & (3) & $(4)$ & (5) \\
\hline Maoist electoral share & $\begin{array}{l}29.624 * * \\
(11.735)\end{array}$ & $\begin{array}{l}36.489 * * * \\
(7.864)\end{array}$ & & & \\
\hline UML electoral share & $\begin{array}{l}23.481 * \\
(14.058)\end{array}$ & & $\begin{array}{c}2.721 \\
(20.233)\end{array}$ & & \\
\hline NC electoral share & $\begin{array}{c}7.815 \\
(7.495)\end{array}$ & & & $\begin{array}{l}-39.672 * * * \\
(10.559)\end{array}$ & \\
\hline Main parties share & & & & & $\begin{array}{l}49.103 * * * \\
(5.848)\end{array}$ \\
\hline Maoist PR & & $\begin{array}{c}7.173 \\
(6.442)\end{array}$ & $\begin{array}{l}-12.634^{* *} \\
(5.881)\end{array}$ & $\begin{array}{c}-17.265 * * * \\
(4.185)\end{array}$ & $\begin{array}{l}27.557 * * * \\
(3.364)\end{array}$ \\
\hline $\begin{array}{l}\text { Maoist PR } \\
\text { x Maoist share }\end{array}$ & & $\begin{array}{c}-33.366 * * * \\
(11.947)\end{array}$ & & & \\
\hline $\begin{array}{l}\text { Maoist PR } \\
\text { x UML share }\end{array}$ & & & $\begin{array}{c}1.325 \\
(24.210)\end{array}$ & & \\
\hline $\begin{array}{l}\text { Maoist PR } \\
\text { x NC share }\end{array}$ & & & & $\begin{array}{l}33.142 * \\
(18.172)\end{array}$ & \\
\hline $\begin{array}{l}\text { Maoist PR } \\
\text { x Main parties share }\end{array}$ & & & & & $\begin{array}{l}-45.558 * * * \\
\quad(5.686)\end{array}$ \\
\hline Civilian casualties & $\begin{array}{c}65.428 \\
(121.956)\end{array}$ & $\begin{array}{c}47.278 \\
(113.510)\end{array}$ & $\begin{array}{c}50.913 \\
(132.733)\end{array}$ & $\begin{array}{c}51.721 \\
(114.975)\end{array}$ & $\begin{array}{c}48.612 \\
(111.010)\end{array}$ \\
\hline Total casualties & $\begin{array}{c}-139.257 * * * \\
(52.755)\end{array}$ & $\begin{array}{l}-132.636 * * \\
(55.676)\end{array}$ & $\begin{array}{l}-104.446 * * \\
(40.694)\end{array}$ & $\begin{array}{c}-118.736 * * * \\
(45.089)\end{array}$ & $\begin{array}{c}-117.042 * * \\
(46.330)\end{array}$ \\
\hline Adult illiteracy rate & $\begin{array}{l}-0.364 \\
(0.743)\end{array}$ & $\begin{array}{l}-0.452 \\
(0.762)\end{array}$ & $\begin{array}{l}-0.518 \\
(0.764)\end{array}$ & $\begin{array}{l}-0.521 \\
(0.775)\end{array}$ & $\begin{array}{l}-0.346 \\
(0.748)\end{array}$ \\
\hline Infant malnutrition & $\begin{array}{c}0.808 \\
(0.562)\end{array}$ & $\begin{array}{c}0.866 \\
(0.584)\end{array}$ & $\begin{array}{c}0.664 \\
(0.507)\end{array}$ & $\begin{array}{c}0.738 \\
(0.531)\end{array}$ & $\begin{array}{c}0.700 \\
(0.519)\end{array}$ \\
\hline Poverty incidence & $\begin{array}{l}1.472 * * \\
(0.693)\end{array}$ & $\begin{array}{l}1.467 * * \\
(0.687)\end{array}$ & $\begin{array}{l}1.504 * * \\
(0.710)\end{array}$ & $\begin{array}{l}1.461 * * \\
(0.692)\end{array}$ & $\begin{array}{l}1.509 * * \\
(0.711)\end{array}$ \\
\hline Road density & $\begin{array}{l}-0.009 \\
(0.006)\end{array}$ & $\begin{array}{l}-0.010 \\
(0.006)\end{array}$ & $\begin{array}{l}-0.011 * \\
(0.006)\end{array}$ & $\begin{array}{l}-0.010^{*} \\
(0.006)\end{array}$ & $\begin{array}{l}-0.010^{*} \\
(0.006)\end{array}$ \\
\hline $\begin{array}{l}\text { Percentage without } \\
\text { safe water }\end{array}$ & $\begin{array}{l}-0.829 * \\
(0.466)\end{array}$ & $\begin{array}{l}-0.757^{*} \\
(0.449)\end{array}$ & $\begin{array}{l}-0.828^{*} \\
(0.483)\end{array}$ & $\begin{array}{l}-0.807^{*} \\
(0.468)\end{array}$ & $\begin{array}{l}-0.845^{*} \\
(0.483)\end{array}$ \\
\hline Population $(1,000 \mathrm{~s})$ & $\begin{array}{c}-0.069 * * * \\
(0.023)\end{array}$ & $\begin{array}{c}-0.070 * * * \\
(0.023)\end{array}$ & $\begin{array}{c}-0.078^{* * *} * \\
(0.026)\end{array}$ & $\begin{array}{c}-0.080^{* * *} \\
(0.027)\end{array}$ & $\begin{array}{c}-0.068^{* * *} * \\
(0.022)\end{array}$ \\
\hline Region dummies & yes & yes & yes & yes & yes \\
\hline Year dummies & yes & yes & yes & yes & yes \\
\hline Observations & 375 & 375 & 375 & 375 & 375 \\
\hline R-squared & 0.224 & 0.229 & 0.214 & 0.222 & 0.225 \\
\hline Number of panels & 75 & 75 & 75 & 75 & 75 \\
\hline
\end{tabular}

Panel-corrected standard errors in parentheses $* * * \mathrm{p}<0.01, * * \mathrm{p}<0.05, * \mathrm{p}<0.1$ 
Table 4: OLS -- Aid Allocation as function of voter support for main parties, UML PR, 2008-2013 observations

(1)

4.045

(17.381)

Maoist electoral share

NC electoral share

Main parties share

UML PR
UML PR
x UML share
UML PR
x Maoist share
UML PR
x NC share
UML PR
x Main parties share

3.123

(11.171)
(3)

(4)

(3)


Table 5: Aid Allocation as function of support for main parties involved in peace agreement, only 2008-2013 observations

\begin{tabular}{|c|c|c|c|c|}
\hline & $(1)$ & $(2)$ & (3) & $(4)$ \\
\hline Other parties share & $\begin{array}{l}-25.147 * * * \\
(9.295)\end{array}$ & $\begin{array}{l}-49.103 * * * \\
(5.848)\end{array}$ & $\begin{array}{l}-3.545 \\
(9.585)\end{array}$ & $\begin{array}{c}-7.486 \\
(26.946)\end{array}$ \\
\hline Maoist PR & & $\begin{array}{c}-18.001 * * * \\
(4.274)\end{array}$ & & \\
\hline $\begin{array}{l}\text { Maoist PR } \\
\text { x Other parties share }\end{array}$ & & $\begin{array}{l}45.558 * * * \\
(5.686)\end{array}$ & & \\
\hline UML PR & & & $\begin{array}{l}18.001 * * * \\
(4.274)\end{array}$ & $\begin{array}{c}20.092 * * * \\
(4.555)\end{array}$ \\
\hline $\begin{array}{l}\text { UML PR } \\
\text { x Other parties share }\end{array}$ & & & $\begin{array}{l}-45.558 * * * \\
(5.686)\end{array}$ & $\begin{array}{c}-47.622 * * * \\
(7.543)\end{array}$ \\
\hline Terai & & & & $\begin{array}{l}-9.376 \\
(9.291)\end{array}$ \\
\hline $\begin{array}{l}\text { UML PR } \\
\text { x Terai }\end{array}$ & & & & $\begin{array}{c}-19.933 * * * \\
(6.660)\end{array}$ \\
\hline $\begin{array}{l}\text { Terai } \\
\text { x Other parties share }\end{array}$ & & & & $\begin{array}{c}3.298 \\
(35.634)\end{array}$ \\
\hline $\begin{array}{l}\text { UML PR x Terai } \\
\text { x Other parties share }\end{array}$ & & & & $\begin{array}{l}28.409 * * \\
(13.842)\end{array}$ \\
\hline Civilian casualties & & $\begin{array}{c}48.612 \\
(111.010)\end{array}$ & $\begin{array}{c}48.612 \\
(111.010)\end{array}$ & $\begin{array}{l}140.667 \\
(90.562)\end{array}$ \\
\hline Total casualties & $\begin{array}{l}-112.614 * * \\
(54.393)\end{array}$ & $\begin{array}{l}-117.042 * * \\
(46.330)\end{array}$ & $\begin{array}{l}-117.042^{* *} \\
(46.330)\end{array}$ & $\begin{array}{l}-133.805^{* *} \\
(51.972)\end{array}$ \\
\hline Adult illiteracy rate & $\begin{array}{l}-0.354 \\
(0.751)\end{array}$ & $\begin{array}{l}-0.346 \\
(0.748)\end{array}$ & $\begin{array}{l}-0.346 \\
(0.748)\end{array}$ & $\begin{array}{l}-0.259 \\
(1.060)\end{array}$ \\
\hline Infant malnutrition & $\begin{array}{c}0.710 \\
(0.516)\end{array}$ & $\begin{array}{c}0.700 \\
(0.519)\end{array}$ & $\begin{array}{c}0.700 \\
(0.519)\end{array}$ & $\begin{array}{c}0.711 \\
(0.512)\end{array}$ \\
\hline Poverty incidence & $\begin{array}{l}1.518^{* *} \\
(0.696)\end{array}$ & $\begin{array}{l}1.509 * * \\
(0.711)\end{array}$ & $\begin{array}{l}1.509 * * \\
(0.711)\end{array}$ & $\begin{array}{l}1.486^{* *} \\
(0.723)\end{array}$ \\
\hline Road density & $\begin{array}{l}-0.010^{*} \\
(0.006)\end{array}$ & $\begin{array}{l}-0.010^{*} \\
(0.006)\end{array}$ & $\begin{array}{l}-0.010^{*} \\
(0.006)\end{array}$ & $\begin{array}{l}-0.008 \\
(0.006)\end{array}$ \\
\hline Percentage without safe water & $\begin{array}{l}-0.842^{*} \\
(0.490)\end{array}$ & $\begin{array}{l}-0.845^{*} \\
(0.483)\end{array}$ & $\begin{array}{l}-0.845^{*} \\
(0.483)\end{array}$ & $\begin{array}{c}-1.068 * * \\
(0.478)\end{array}$ \\
\hline Population $(1,000 \mathrm{~s})$ & $\begin{array}{c}-0.068 * * * \\
(0.024) \\
\end{array}$ & $\begin{array}{c}-0.068 * * * \\
(0.022)\end{array}$ & $\begin{array}{c}-0.068 * * * \\
(0.022) \\
\end{array}$ & $\begin{array}{c}-0.058^{* *} \\
(0.025) \\
\end{array}$ \\
\hline Region dummies & yes & yes & yes & yes \\
\hline Year Dummies & yes & yes & yes & yes \\
\hline Observations & 375 & 375 & 375 & 375 \\
\hline R-squared & 0.218 & 0.225 & 0.225 & 0.228 \\
\hline Number of panels & 75 & 75 & 75 & 75 \\
\hline
\end{tabular}

Panel-corrected standard errors in parentheses $* * * \mathrm{p}<0.01, * * \mathrm{p}<0.05, * \mathrm{p}<0.1$ 
aid allocations and voting for the Nepali Congress when the Maoists do not hold power. But as in model 2, with the Maoists in charge this negative effect washes out. ${ }^{15}$ Together, these three models provide solid evidence that aid allocations under CPN(M) leadership of the Peace and Reconstruction ministry did not favor the voters of any of the three main parties. To confirm this insight, in model 5 we pool the vote share for all major parties and repeat the exercise from the previous three models, with the same outcome. Main parties share is only associated with higher aid allocations when the Maoists do not hold power.

Above we discussed battlefield casualties as alternative measure for political support of the CPN(M). When estimating models $1 \& 2$ (and model 2 in table 4) with this alternative specification, again there is no evidence of a relationship between support for the Maoists and aid allocations, regardless of the party in power. For space reasons, these results are reported in the online supplemental appendix.

Despite these encouraging findings, the results in Table 3 also reveal that electoral shares do matter for aid allocations in the three years in which the Ministry for Peace and Reconstruction was not in Maoist hands. To confirm this notion, table 4 repeats the exercise with the UML in charge of the ministry. Interestingly, like the CPN(M), the UML does not privilege its own supporters when holding power (model 1). But under its leadership aid allocations are higher in districts that voted Maoist (model 2), and they increase even more when looking at the vote share for the three main parties combined (model 4). For a one standard deviation increase in the main parties electoral share (a plus of 24.5 percentage points), per capita aid allocations increase by 11.20 dollars (relative to a mean of 36.30 dollars). At the same time, under UML leadership, districts supporting the Nepali Congress see lower aid allocations (model 3), though the substantive effect is modest (a drop of 4.80 dollars for a one standard deviation or 30 percentage point increase in electoral share).

\footnotetext{
${ }^{15}$ Chi-squared $(1 \mathrm{dgf})=0.14, \mathrm{p}>$ chi-squared $=0.70$.
} 
Overall the models in tables 3 and 4 provide mixed evidence for the role of partisanship in post-conflict aid allocations. Neither the Maoists nor the UML appear to privilege their own voters when holding the Ministry of Peace and Reconstruction. This is a strong indicator that spoils politics did not have an influence on reconstruction aid after the 2008 election. However, aid allocations appear to be sensitive to voting with the UML in charge of the ministry, but not in the sense usually associated with spoils politics. Instead, the UML appears to positively support $\mathrm{CPN}(\mathrm{M})$ voting areas. It is possible that this constituted a reaction to the unexpected electoral success of the Maoists, in an attempt to win back support, though we find little evidence of this in contemporary published records. Overall it appears that the peace settlement was relatively successful in helping to overcome conventional forms of spoils politics where parties directly cater to their own supporters (hypothesis 1).

We next turn to the issue of marginalized groups that were not party to the conflict. In line with hypothesis 2 , if the peace agreement was successful, we should not observe systematic discrimination against these groups, with aid being allocated according socioeconomic need. As discussed above, we use the electoral share for parties other than the major three (CPN(M), UML, NC) as indicative of lacking alignment with either the Maoist cause or the government during the civil war, as marginalized areas closely track with poor voting results for these parties. As a result, the empirical approach is complementary to the analysis of partisan patterns above. In table 5 we present some of the previous models, recoded in a way that emphasizes the effect of lower electoral support for the main parties. Model 1 shows that voting for other parties is strongly associated with lower aid allocations. Models 2 and 3 report substantively the same information as model 5, table 3 and model 4, table 4, but with the Main parties share variable recoded as Other parties share. We can see that under the Maoists aid allocations do not differ in districts that support other parties 
(model 2), while under UML leadership voting for other parties is associated with lower aid allocations (model 3).

These patterns raise the question about the source of the UML's animosity towards areas that did not vote for major parties. One of the contentious issues in post-conflict Nepal is how the new federal system, which was introduced as part of the peace agreement, maps onto population cleavages. While the Maoists supported drawing district boundaries along ethnic lines, both NC and UML opposed such districts on grounds of promoting particularism (Strasheim \& Bogati 2016). The most prominent dispute in concrete terms concerns the relative autonomy awarded to majority Hindu population groups in the Terai, which continue to be deemed by some Nepalese elites to be too closely aligned to India. ${ }^{16}$

As we have seen in the descriptive statistics, non-support for the main parties geographically maps well onto the Terai region. This raises the important question whether aid allocations under the UML are influenced primarily by electoral considerations or are driven by more fundamental ethnic antagonism. Unfortunately, we were unable to obtain reliable data on ethnic composition broken down by district. Instead, in model 4 we include an indicator variable for all districts that geographically belong to the lower Terai region (see online supplemental appendix for coding). To parse the source of lower aid allocations, we add interactions of the Terai variable with the UML PR dummy, and the other parties electoral share variable, as well as a three-way interaction of the Terai variable, the UML PR dummy, and the electoral share variable. This allows us to evaluate whether aid allocations under UML control of the Ministry of Peace and Reconstruction are a function of voting behavior or reflect discrimination against the Terai region.

\footnotetext{
${ }^{16}$ According to Nayak (2011) and Miklian (2009) the Pahadis - people from the hill region - and political elites in Kathmandu believe that India has been supporting the 'One Madhes One Pradesh' demand and that it aims to balkanise Nepal leveraging the Madhesi population group.
} 
Model 4 in table 5 reports the results. To help with interpretation we consider the following quantities of interest (table 6): The marginal effect of having the UML in power a) with no support for other parties \& outside the Terai region; b) with full support for other parties, outside the Terai region; c) with no support for other parties, in the Terai, d) with full support for other parties, in the Terai. We are interested in comparing the influence that voting behavior has on aid allocations under UML leadership inside and outside the Terai, i.e. the difference in marginal effects between scenarios a) and b), and c) and d). Both inside and outside the Terai aid allocations drop when the UML holds power in reaction to voting for other parties. However, this drop is considerably smaller inside the Terai. Whereas outside the Terai moving from zero to 100 percent electoral share incurs a penalty of 47.62 dollars per capita, inside the Terai this decrease is only 19.21 dollars. Clearly, electoral behavior plays a larger role for aid allocations under UML leadership outside the Terai.

Table 6: Comparison of marginal effects of UML PR

\begin{tabular}{|c|c|c|}
\hline \multicolumn{3}{|c|}{$x_{1}=$ vote share other parties $; x_{2}=$ Terai } \\
\hline Scenario & Effect of UML PR & Differences \\
\hline a) $x_{1}=0 ; x_{2}=0$ & $20.09^{* * *}$ & \\
\hline b) $x_{1}=1 ; x_{2}=0$ & $20.09-47.62=-27.53^{* * *}$ & b) $-a)=-47.62$ \\
\hline c) $x_{1}=0 ; x_{2}=1$ & $20.09-19.93=0.16$ & c) $-a)=-19.93$ \\
\hline d) $x_{1}=1 ; x_{2}=1$ & $20.09-47.62-19.93+28.41=-19.05^{* * *}$ & $\begin{array}{c}d)-c)=-19.21 \\
d)-b)=8.48\end{array}$ \\
\hline & $* * * \mathrm{p}<0.01, * * \mathrm{p}<0.05, * \mathrm{p}<0.1$ & \\
\hline
\end{tabular}

How does the effect of voting behavior compare to any animus displayed towards the Terai region when setting voting aside? The answer is not straightforward. If the major parties have full electoral support (scenarios a) and c)), districts in the Terai are worse off under the UML, with on average 19.93 dollars per capita less in aid. However, when fully 
supporting other parties (scenarios b) and d)), districts in the Terai come out ahead, with 8.48 dollars more in aid per capita than districts outside.

Overall then, there is evidence that with the UML in charge of the Ministry of Peace and Reconstruction there is a penalty for voting for other parties, and likewise for districts in the Terai, but the later heavily depends on voting behavior. This is because the two conditioning factors move in opposite directions. Where other parties are strong in the Terai there is less disadvantage in aid allocations than where they are weak. In fact, aid allocations to a district in the Terai that elects 100 percent representatives from other parties are statistically indistinguishable under the UML and the CPN(M) (scenario c).

To sum up, there is a clear association between a lack of major party support and lower aid allocations during the reconstruction phase, contradicting hypothesis 2 . Before interpreting this as unequivocal failing of the peace agreement, it is important to point out that the substantive shortfalls in aid to marginalized districts is only occurring in the two years under which the UML held the Ministry of Peace and Reconstruction. This is in line with the UML as a party that supports a Kathmandu-centered view of the Nepalese polity. Even then, when looking at the Terai as region that hosts the most visible ethnic cleavage in Nepali politics, aid shortfalls occur under the UML, but only in districts that provide relatively high support to the major parties. Where other parties are strong, there is no aid penalty under UML leadership. As the political gains of parties supporting the Madhesi in the Terai came at the expense of the UML, NC and CPN(M) (Miklian 2009), this suggests that the UML is sensitive to grievances in the region when they find open political expression, and a more neglectful approach is taken where political support for the main parties is taken for granted.

On balance though, we have to reject hypothesis 2 . The political settlement after the civil war was precisely meant to take politics out of the question of distributional fairness 
in Nepali politics. The role of the UML in skewing aid allocations during the reconstruction period suggests that this was not achieved. This squares with the political discussions about the future shape of the Nepalese federalism, which were only resolved after the 2015 earthquake in the Second Constituent Assembly. Future work will need to show whether this final settlement was more successful in bridging the social divides that were still visible during the reconstruction period.

\section{Conclusion}

This paper explores the important role of political capture of foreign aid for successful reconstruction in post-conflict societies. We focus on Nepal to explore to what extent power sharing enshrined in the $2006 \mathrm{CPA}$ and the 2007 Interim Constitution insulated aid allocations from partisan influence. We theorize that areas that supported the former warring factions were rewarded with more aid then areas where people did not join the fight, and we find statistical evidence to this effect. Importantly, we are able to show that with the UML in control of the Ministry of Peace and Reconstruction, districts that support neither of the main parties in the 2008 elections received substantially less foreign aid, after controlling for human development indicators and other factors associated with the need for aid funding. While this only indirectly maps onto past conflict behavior, the possibility that active conflict participation is a prerequisite for adequate political presentation and leverage during peace negotiations has troubling implications for the incentives of nonaligned groups in multi-group or multi-ethnic conflicts. If staying on the side lines does not pay, escalation might be difficult to prevent. Outside mediators need to take lessons about the role of nonaligned groups seriously. More research is needed to establish the relevance of this link in different conflict scenarios.

On the positive side, we could not find evidence of traditional spoils politics, where the party in power channels aid towards its own supporters. This has encouraging implications 
for the effectiveness of power sharing in Nepal. Political capture of aid flows in postconflict situations has the potential to undermine the donor community's policy response and entrench distributional inequalities that can feed into future political unrest. Developing a better theoretical understanding of the political economy of aid allocation processes in post-conflict environments is an important first step. Also needed is more fine-grained empirical analysis of sub-national processes. The increasing availability of geo-coded data of aid flows, political entities, and political alignments such as those based on ethnicity should enable researchers to make progress on this important subject. 


\section{Bibliography}

Acemoglu, Daron, and James A. Robinson. 2000. "Why Did The West Extend The Franchise? Democracy, Inequality, and Growth in Historical Perspective." Quarterly Journal of Economics :1167-1199.

Acharya, Avidit. 2009. "The Maoist insurgency in Nepal and the political economy of violence." In The Maoist insurgency in Nepal: Revolution in the twenty-first century, eds. Mahendra Lawoti and Anup Kumar Pahari. Routledge, 263-284.

AidData. 2017. WorldBank_GeocodedResearchRelease_Level1_v1.4.2 geocoded dataset. Williamsburg, VA and Washington, DC: AidData. Accessed on [04/02/2019]. http://aiddata.org/research-datasets.

AidData. 2016. NepalAIMS_GeocodedResearchRelease_Level1_v1.4.1 geocoded dataset. Williamsburg, VA and Washington, DC: AidData.

Atkinson, James, Allen Hicken, and Nico Ravanilla. "Pork \& Typhoons: The Political Economy of Disaster Assistance in the Philippines." Ann Arbor 1001 (2011): 48109-1045.

Beck, N. and Katz, J.N., 1995. What to do (and not to do) with time-series cross-section data. American political science review, pp.634-647.

Briggs, Ryan C. 2014. "Aiding and abetting: project aid and ethnic politics in Kenya." World Development 64:194-205.

Bueno de Mesquita, Bruce, and Alastair Smith. 2009. "A Political Economy of Aid." International Organization 63:309-340.

Buhaug, Halvard, Lars-Erik Cederman, and Jan Ketil Rod. 2008. "Disaggregating ethnonationalist civil wars: A dyadic test of exclusion theory." International Organization 62:531-551.

Collier, Paul, V. L. Elliott, Havard Hegre, Anke Hoeffler, Marta Reynal-Querol, and Nicholas Sambanis. 2003. Breaking the Conflict Trap: Civil War and Development Policy. Washington, DC: The World Bank.

Collier, Paul, and Anke Hoeffler. "Aid, policy and growth in post-conflict societies." European economic review 48, no. 5 (2004): 1125-1145.

Dal Bó, Ernesto, and Robert Powell. 2009. "A Model of Spoils Politics." American Journal of Political Science 53:207-222.

De Mesquita, Bruce Bueno, and Alastair Smith. "A political economy of aid." International Organization 63, no. 2 (2009): 309-340.

Department for international Development. 2018. "DFID Nepal". Accessed online on 99-2018

at https://assets.publishing.service.gov.uk/government/uploads/system/uploads/attac hment_data/file/636546/Nepal1.pdf

Deraniyagala, Sonali. 2005. "The political economy of civil conflict in Nepal." Oxford Development Studies 33:47-62.

Druckman, Daniel, and Cecilia Albin. 2011. "Distributive justice and the durability of peace agreements." Review of International Studies :1137-1168. 
Ejdemyr, Simon, Eric Kramon, and Amanda Lea Robinson. 2017. "Segregation, ethnic favoritism, and the strategic targeting of local public goods." Comparative Political Studies

Fearon, James D., Macartan Humphreys, and Jeremy M. Weinstein. 2009. "Can Development Aid Contribute to Social Cohesion After Civil War? Evidence From a Field Experiment in Post-Conflict Liberia." American Economic Review 99:287291.

Findley, Michael G. 2018. "Does foreign aid build peace?” Annual Review of Political Science. 21:359-384.

Franck, Raphael, and Ilia Rainer. 2012. "Does the leader's ethnicity matter? Ethnic favoritism, education, and health in sub-Saharan Africa." American Political Science Review.106:294-325.

Haass, Felix, and Martin Ottmann. "Profits from peace: The political economy of powersharing and corruption." World Development 99 (2017): 60-74.

Haass, Felix. "The democracy dilemma. Aid, power-sharing governments, and postconflict democratization." Conflict Management and Peace Science (2019): 0738894219830960.

Hachhethu, K., 2006. The Nepali State and the Maoist Insurgency. Himalayan People's War: Nepal's Maoist Revolution (Bloomington: Indiana University Press, 2004, p. 61.

Hartzell, Caroline, and Matthew Hoddie. "Institutionalizing peace: power sharing and post-civil war conflict management." American Journal of Political Science 47, no. 2 (2003): 318-332.

Hodler, Roland, and Paul A. Raschky. Foreign aid and enlightened leaders. No. 10.05. Working Paper, Study Center Gerzensee, 2010.

Huang, Reyko. 2016. The wartime origins of democratization: civil war, rebel governance, and political regimes. Cambridge: Cambridge University Press.

Hutt, M., 2004. Introduction: monarchy, democracy and Maoism in Nepal (pp. 1-20). Hurst \& Company.

Jablonski, Ryan S. 2014. "How aid targets votes: the impact of electoral incentives on foreign aid distribution." World Politics. 66(2): 293-330.

Huang, Reyko. 2016. The wartime origins of democratization: civil war, rebel governance, and political regimes. Cambridge: Cambridge University Press.

Joshi, Madhav, and T David Mason. 2007. "Land tenure, democracy, and insurgency in Nepal: Peasant support for insurgency versus democracy." Asian Survey 47:393414.

Joshi, Madhav, and Subodh Raj Pyakurel. 2015. "Individual-level data on the victims of Nepal's civil war, 1996-2006: a new data set." International Interactions 41:601619.

Kang, Seonjou, and James Meernik. 2005. "Civil war destruction and the prospects for economic growth.” The Journal of Politics 67:88-109. 
Kantha, Pramod K. 2010. "Maoist-Madhesi dynamics and Nepal's peace process." In: TheMaoist Insurgency in Nepal: Revolution in the twenty-first century, eds. Mahendra Lawoti and Anup K. Pahari. Abingdon: Routledge, 156-172.

Kollman, K., Hicken, A., Caramani, D., Backer, D. and Lublin, D., 2011. Constituencylevel elections archive. Ann Arbor, mich.: Center for Political studies, University of michigan. At http://www. electiondataarchive. org, accessed may.

Lawoti, Mahendra. 2010. "Evolution and growth of the Maoist insurgency in Nepal." In: The Maoist Insurgency in Nepal: Revolution in the twenty-first century, eds. Mahendra Lawoti and Anup K. Pahari. Abingdon: Routledge, 3-30.

Lawoti, Mahendra. 2012. "Ethnic Politics and the Building of an Inclusive State." In: Nepal in Transition: From People's War to Fragile Peace, eds. Sebastian von Einsiedel, David M. Malone, and Suman Pradhan. 129-159.

Mansuri, Ghazala, and Vijayendra Rao. 2004. "Community-Based and -Driven Development: A Critical Review." World Bank Research Observer 19:1-39.

Miklian, J., 2009. Nepal's Terai: Constructing an ethnic conflict (p. 5). Oslo: PRIO.

Morrison, Kevin M. 2009. "Oil, Nontax Revenue, and the Redistributional Foundations of Regime Stability." International Organization 63:107-138.

Murshed, S Mansoob, and Scott Gates. 2005. "Spatial-horizontal inequality and the Maoist insurgency in Nepal." Review of development economics 9:121-134.

Nielsen, Richard A., Michael G. Findley, Zachary S. Davis, Tara Candland, and Daniel L. Nielson. 2011. "Foreign Aid Shocks as a Cause of Violent Armed Conict." American Journal of Political Science 55:219-232.

Nayak, N., 2011. The Madhesi Movement in Nepal: Implications for India. Strategic Analysis, 35(4), pp.640-660.

Pokharel, T., 2015. Poverty in Nepal: Characteristics and challenges. Journal of Poverty, Investment and Development, 11 .

Savun, Burcu, and Daniel C. Tirone. 2012. "Exogenous Shocks, Foreign Aid, and CivilWar." International Organization 66:363-393.

Shakya, Sujeev. 2012. "Unleashing Nepal's economic potential: A business perspective." In Nepal in Transition: From People's War to Fragile Peace, eds. Sebastian von Einsiedel, David M. Malone, and Suman Pradhan. Cambridge University Press New Dehli, 114-128.

Sharma, Sudheer. 2004. "The Maoist Movement: An Evolutionary Perspective." In Himalyan 'People's War': Nepal's Maoist Rebellion, edited by Michael Hutt, 3857. London: Hurst.

Sharma, Sagar Raj, Bishnu Raj Upreti, and Ulrike Müller-Böker. 2014. "Negotiating Access to land in Nepal." Journal of Contemporary Asia 44:521-539.

aShneiderman, Sara, and Mark Turin. 2004. The path to Jan Sarkar in Dolakhadistrict: Towards an ethnography of the Maoist movement. In Himalyan 'People's War': Nepal's Maoist Rebellion, edited by Michael Hutt, 79-111. London: Hurst.

Strasheim, Julia, and Subindra Bogati. 2016. "Nepal's quest for federalism: a driver of new violence." GIGA Focus Asia. 1. 
Steinwand, Martin C. 2015. "Foreign Aid and Political Stability." Conflict Management and Peace Science 32:395-424.Sundberg, R. and Melander, E., 2013. Introducing the UCDP georeferenced event dataset. Journal of Peace Research, 50(4), pp.523532.

Winters, Matthew S. 2014. "Targeting, accountability and capture in development projects." International Studies Quarterly 58:393-404. 